\title{
Early Carboniferous gabbro and basalt in the St. Peters area, southern Cape Breton Island, Nova Scotia
}

\author{
S.M. Barr ${ }^{1}$, A.L. Grammatikopoulos ${ }^{1}{ }^{*}$, and G.R. Dunning ${ }^{2}$ \\ ${ }_{1}$ Department of Geology, Acadia University, Wolfville, Nova Scotia B0P IX0, Canada \\ ${ }^{2}$ Department of Earth Sciences, Memorial University, St. John's, Newfoundland AIB 3X5, Canada
}

Date Received December 16, 1994

Date Accepted February 22, 1995

\begin{abstract}
Small gabbroic plutons and minor mafic volcanic rocks occur in the St. Peters area of southwestern Cape Breton Island. $\mathrm{U}-\mathrm{Pb}$ dating of zircon and baddeleyite show that the gabbro has an Early Carboniferous age of $339 \pm 2 \mathrm{Ma}$, similar to the age of the surrounding sedimentary units of the Horton and Windsor groups. The gabbros were intruded at shallow depth, consistent with their association with minor mafic volcanic rocks. Petrological studies suggest that evolution of the gabbros involved fractionation of $\mathrm{Mg}$-rich olivine and pyroxene, but not significant plagioclase. The chemical characteristics of the suite have been partly modified by alteration, evidenced in albitization of plagioclase and zones of carbonate alteration, but generally indicate a continental within-plate tectonic setting and tholeiitic affinity. The parent magma may have been depleted in heavy rare-earth elements, and was possibly derived from a garnet-bearing mantle source. The St. Peters gabbros and basalts are part of widespread mid-Devonian to Carboniferous igneous activity in Atlantic Canada, apparently related to extension during the development of the Maritimes Basin.
\end{abstract}

De petites intrusions ignées gabbroïques et de faibles quantités de roches volcano-mafiques sont présentes dans la région de St. Peters, dans le sud-ouest de l'île du Cap-Breton. Une datation au U-Pb à partir de zircon et de baddeleyite révèle que le gabbro est âgé de $339 \pm 2 \mathrm{Ma}$ et qu'il remonte donc au Carbonifère inférieur, similairement aux unités sédimentaires des groupes de Horton et de Windsor. Les gabbros ont été pénétrés à une faible profondeur, conformément à leur association avec les roches volcano-mafiques. Des études pétrologiques permettent de supposer que l'évolution des gabbros a comporté un fractionnement d'olivine et de pyroxène riches en $\mathrm{Mg}$, mais pas de fractionnement de plagioclase important. Les caractéristiques chimiques de la série ont été partiellement modifiées par altération, comme le démontrent l'albitisation du plagioclase et les zones d'altération du carbonate, mais elles révèlent généralement une compaction tectonique intra-plaque continentale et une affinité tholéiitique. Le magma parental a pu être appauvri d'éléments lourds des terres rares et il provient possiblement d'une source mantélique grenatifere. Les gabbros et les basaltes de St. Peters font partie de l'activité ignée générale du milieu du Dévonien au Carbonifêre dans les provinces de l'Atlantique, laquelle est apparemment reliée à l'extension survenue pendant le développement du bassin des Maritimes.

[Traduit par la rédaction]

\section{INTRODUCTION}

Small gabbroic plutons and minor mafic volcanic rocks occur in association with Late Devonian(?) and Lower Carboniferous sedimentary rocks in the St. Peters area of southern Cape Breton Island (Figs. 1, 2). They have been an intriguing problem in Nova Scotian geology because of uncertainty about their age and hence about their geological significance. Weeks (1954, 1964) considered them to be of Early Carboniferous age, but other workers assumed ages ranging from Late Precambrian (Keppie and Smith, 1978) to Mesozoic (Durocher, 1974). A Late Precambrian - Cambrian age has been accepted in most recent publications (e.g., Keppie, 1979; Donohoe and Grantham, 1989), although a K-Ar date of $347 \pm 36 \mathrm{Ma}$ was determined for biotite from one of the gabbros by Wanless et al. (1979), and $\mathrm{Rb}-\mathrm{Sr}$ whole rock and biotite analyses yielded a two-point isochron indicating an age of $298 \mathrm{Ma}$ (R.F. Cormier, personal communication cited by Keppie and Smith, 1978). Keppie and Smith
(1978) considered these dates to be unreliable, suggesting that they are either cooling ages or a reflection of reheating during the Acadian Orogeny and/or Maritime Disturbance. In addition to uncertainty about the age, the petrological characteristics of the gabbros and associated volcanic rocks were not well known. Previous studies were limited in scope and consisted mainly of major element geochemistry (Davis, 1972; Durocher, 1974; Keppie and Smith, 1978); they did not lead to a definitive interpretation of either chemical character or tectonic setting.

We report here the results of a study of the St. Peters gabbros and associated volcanic rocks, which included mapping, petrological work, and $\mathrm{U}-\mathrm{Pb}$ dating of zircon and baddeleyite. Our data confirm the interpretation of Weeks $(1954,1964)$ that the rocks are of Early Carboniferous age, and also suggest that they are tholeiites formed in a continental within-plate extensional setting.

\footnotetext{
*Present address: Department of Geological Sciences, Queens University, Kingston, Ontario K7L 3N6, Canada
} 


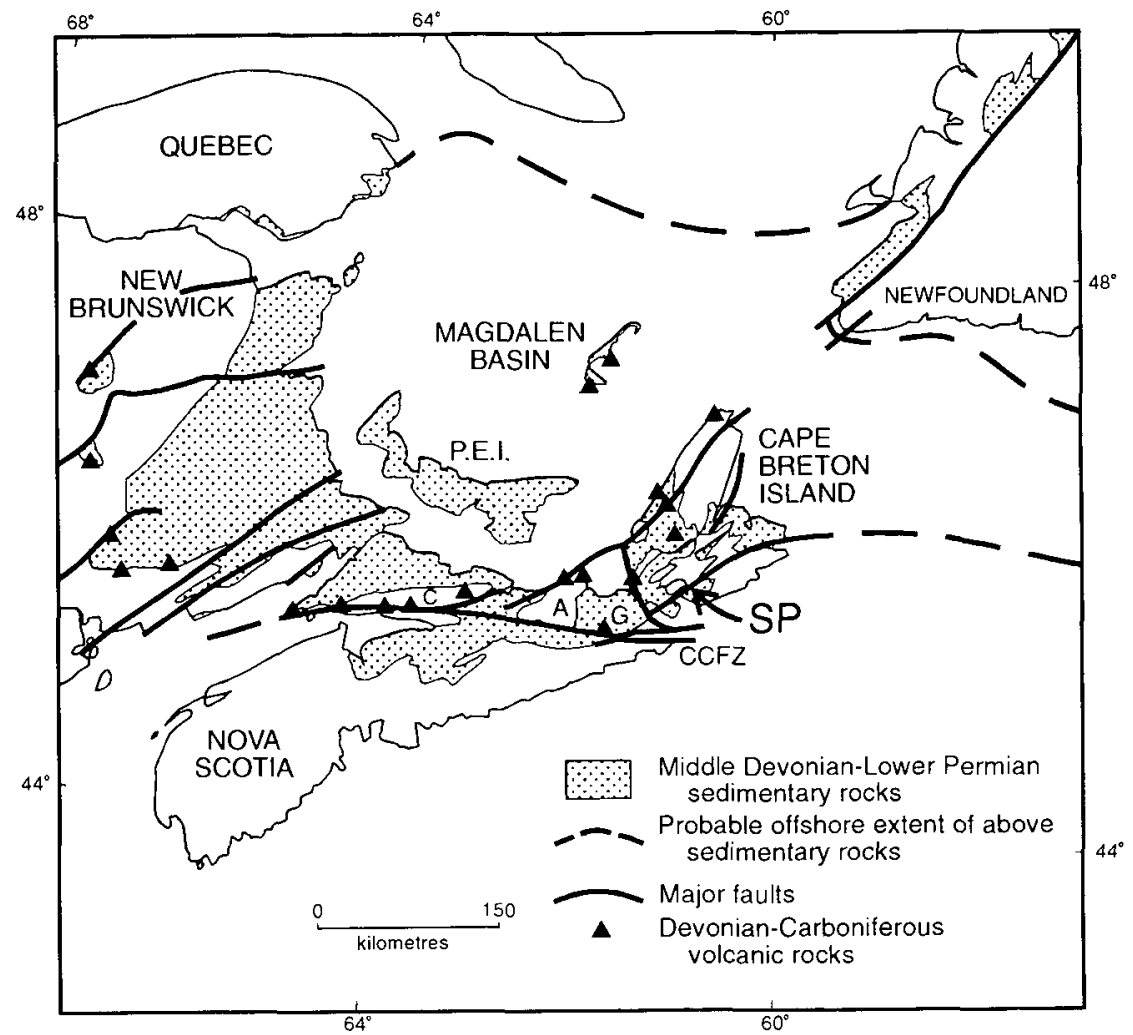

Fig. 1. Outline map of the Maritime provinces showing the location of the St. Peters area gabbros (arrow labelled SP). The area underlain by Middle Devonian - Lower Permian sedimentary rocks is the Maritimes Basin. Triangles represent approximate locations of Devonian - Carboniferous volcanic rocks mentioned in the text: Fisset Brook Formation and correlative units in Cape Breton Island, Guysborough area (G), Fountain Lake Group and associated plutonic units in the Cobequid Highlands, the Magdalen Islands, and various areas in New Brunswick (after Fyffe and Barr, 1986). Map is modified after Piper et al. (1993) and Jansa et al. (1993). Abbreviations: $\mathrm{SP}=\mathrm{St}$. Peters area, G=Guysborough area, CCl $7 .=$ Cobequid - Chedabucto fault zone, PEI = Prince Edward Island.

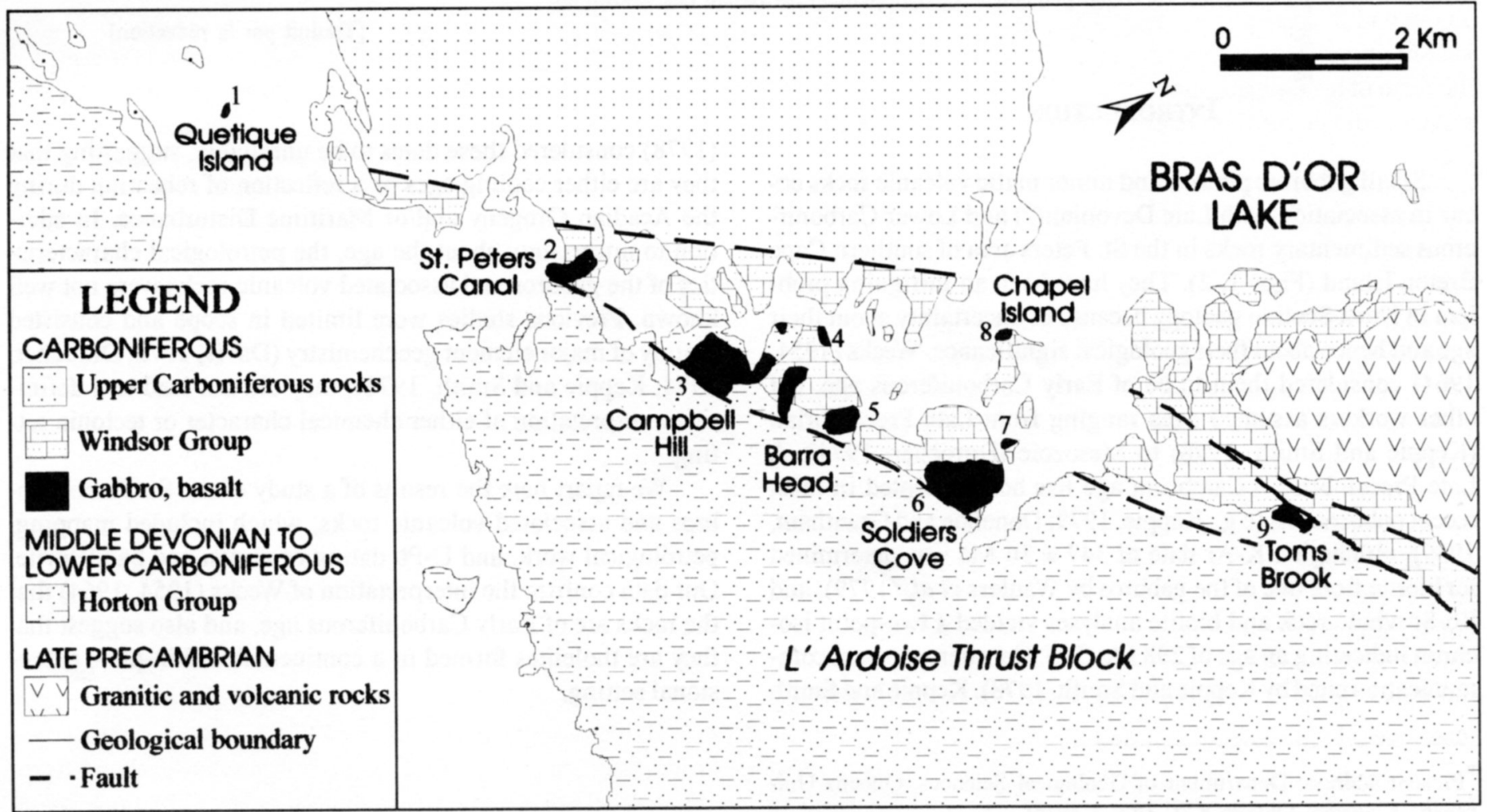

Fig. 2. Geological map showing distribution of gabbroic plutons and volcanic rocks in the St. Peters area. 1, Quetique island gabbro; 2, St. Petcrs Canal gabbro; 3, Campbell Hill gabbro; 4, Macleans Point basalt; 5, Barra Head gabbro (two bodies); 6, Soldiers Cove West gabbro; 7, Alick Island gabbro; 8, Chapel island basalt; 9, Toms Brook gabbro. Map is modified after Weeks (1964) and Keppie and Smith (1978). 


\section{Geological SetTing}

The gabbroic bodies occur in a fault-bounded linear belt (Figs. 1, 2), called the Lennox Passage - St. Peters lineament (Keppie and Smith, 1978), at the margin of the L'Ardoise thrust block of Weeks $(1954,1964)$. They are surrounded by sedimentary rocks, mainly of the Lower Carboniferous Windsor Group. The underlying Upper Devonian to Lower Carboniferous Horton Group occurs mainly south of the plutons in the L'Ardoise thrust block (Fig. 2). The plutons have been assigned informal names based on appropriate geographic locations (Appendix A; Fig. 2).

The shapes of the plutons and the presence of fine-grained to glassy rocks that appear to represent chilled margins suggest an intrusive relationship with the surrounding sedimentary rocks, but no evidence of contact metamorphism was observed around any of the intrusions. Weeks (1954) reported that the gabbros intruded strata of both the Horton Group and the lower part of the Windsor Group, but did not describe the evidence for this intrusive relationship. In contrast, Keppie and Smith (1978) suggested that the contacts with the Carboniferous rocks are entirely faulted or unconformable, in support of their interpretation that the gabbros are Precambrian in age.

Our observations confirm that, where exposed, contacts appear to be either faults or unconformities. On Quetique Island (Fig. 2), a faulted contact is exposed between the Quetique Island gabbro and folded limestone of the Windsor Group, with fault breccia developed in both units. At the southern contact of the St. Peters Canal gabbro (\#2, Fig. 2), a gap in exposure of about $1 \mathrm{~m}$ separates brecciated gabbro from siltstone, also suggesting the presence of a fault. Along the coast north of the Campbell Hill gabbro (\#3, Fig. 2), a layer of gabbro, about 5 to $7 \mathrm{~m}$ in width, occurs between sandstone outcrops. Although the gabbro appears to be conformable with the sandstone and has the form of a small sill, the sandstone, which exhibits well preserved sedimentary lamination, shows no evidence of contact metamorphism. The Toms Brook gabbro (\#9, Fig. 2) is unconformably overlain by a conglomerate containing pebbles and cobbles of gabbro, as well as granite, sandstone, and shale. On the basis of miospores and acritarchs recovered from sedimentary samples from nearby locations by Utting (1977), Keppie and Smith (1978) suggested that the conglomerate is part of the Horton Group and of Middle Devonian to Early Carboniferous age. However, based on the U-Pb age for the St. Peters Canal gabbro reported below, the fossiliferous samples may not be from the same unit as the conglomerate.

In places, the plutons contain features such as interstitial granophyric intergrowths, pegmatoid patches, and miarolitic cavities which indicate that they are high-level intrusions. In several areas they are autobrecciated and display intense carbonate alteration. Small areas of mafic volcanic rocks are associated with the gabbros, although exposure is poor and interlayering of volcanic and sedimentary rocks cannot be demonstrated. On Chapel Island (\#8, Fig. 2), the basalt is amygdaloidal and occurs with minor basaltic tuff; similar basalt also occurs near MacLean Point (\#4, Fig. 2). Glassy basaltic rocks are present locally in the Soldiers Cove West pluton (\#6, Fig.
2), and areas of fine-grained rocks of possible extrusive origin also were found in several other plutons.

On Alick Island (\#7, Fig. 2), fine-grained gabbro forms thin layers that appear to be the result of multiple injection of magma in sheeted dykes.

The only felsic igneous rocks observed in the St. Peters area are two pink felsic dykes, one about $20 \mathrm{~cm}$ in width parallel to a prominent joint plane in the St. Peters Canal gabbro, and the other of similar size in the Campbell Hill gabbro. These felsic dykes appear very altered, with abundant epidote and manganese minerals. Due to their small size and intense alteration, no chemical studies were done on these dykes.

\section{Petrography}

The most abundant rock type in the plutons is medium- to coarse-grained gabbro, dominated by plagioclase and clinopyroxene with minor amphibole, biotite, opaque minerals, and other accessory phases, including apatite, zircon, and baddeleyite. Relict olivine was observed only in the Quetique Island gabbro, but olivine pseudomorphs are present in some samples from the St. Peters Canal gabbro, and olivine has also been reported in the Toms Brook gabbro (Douglas and Goodman, 1940), although it is not present in our samples. Textures are mainly intergranular to ophitic or sub-ophitic. Rare pegmatoid patches contain coarse plagioclase and interstitial amphibole and biotite. Fine-grained gabbro, generally found near margins of the plutons, is more varied in texture than the medium- to coarse-grained gabbro, and also more altered. Some varieties are porphyritic with plagioclase phenocrysts, and groundmass plagioclase displays alignment as a result of flow. Interstitial glass is present in several of the fine-grained samples. The amygdaloidal basaltic flows on Chapel Island and at MacLeans Point contain sparse plagioclase phenocrysts, and amygdales contain carbonate and chlorite. The basalts show intense alteration to saussurite, chlorite, epidote, and carbonate.

Plagioclase forms 50 to $60 \%$ of most gabbro samples and shows moderate to intense alteration to sericite, albite, carbonate minerals, and epidote. Compositions determined optically and by electron microprobe are about $\mathrm{An}_{60}$ in the least altered grains. Clinopyroxene and its alteration products (chlorite, epidote, uralite, biotite, carbonate minerals, and iron oxides) comprise between 30 and $40 \%$ of the gabbro. Analyses of several grains in six samples indicate that clinopyroxene is of salite composition (average $\mathrm{Ca}: \mathrm{Mg}: \mathrm{Fe}=45: 43: 12$ ), but with variable amounts of minor components $\mathrm{Cr}, \mathrm{Ni}, \mathrm{Ti}$, and $\mathrm{Na}$ (Grammatikopoulos, 1992). Relict olivine in the Quetique Island gabbro ranges in composition from Fo80 to Fo77, with $\mathrm{NiO}$ content of 0.31 to $0.15 \mathrm{wt}$ \% (Grammatikopoulos, 1992). The high proportion (65\%) of olivine and pyroxene in this sample suggests that it is a cumulate.

Amphibole and mica occur around the rims of clinopyroxene grains, as well as interstitially, in the mediumto coarse-grained gabbro samples. The amphibole exhibits dark brown to green pleochroism, and electron microprobe analyses of amphibole in olivine gabbro sample \#1 from Quetique Island indicated pargasitic composition. The mica is pleochroic in 
Table 1. Major and trace element analyses from the St. Peters gabbros.

\begin{tabular}{|c|c|c|c|c|c|c|c|c|c|c|c|c|}
\hline & 1 & 2 & 3 & 4 & 5 & 6 & 7 & 8 & 9 & 10 & 11 & 12 \\
\hline $\mathrm{SiO}_{2}$ & 39.25 & 49.10 & 47.65 & 48.64 & 43.20 & 47.63 & 49.01 & 50.46 & 48.76 & 50.78 & 48.41 & 51.23 \\
\hline $\mathrm{TiO}_{2}^{2}$ & 1.04 & 2.09 & 3.54 & 2.14 & 4.09 & 2.94 & 2.60 & 2.98 & 2.32 & 2.81 & 3.03 & 2.13 \\
\hline $\mathrm{Al}_{2} \mathrm{O}_{3}$ & 8.12 & 16.65 & 15.64 & 16.53 & 12.97 & 16.18 & 16.41 & 13.51 & 14.12 & 14.52 & 14.63 & 17.14 \\
\hline $\mathrm{Fe}_{2} \mathrm{O}_{3}$ & 14.47 & 9.11 & 12.64 & 10.06 & 18.47 & 12.83 & 10.68 & 13.62 & 13.11 & 11.34 & 12.94 & 6.65 \\
\hline $\mathrm{MnO}$ & 0.38 & 0.16 & 0.23 & 0.13 & 0.17 & 0.15 & 0.09 & 0.17 & 0.06 & 0.15 & 0.46 & 0.09 \\
\hline $\mathrm{MgO}$ & 20.75 & 5.22 & 5.18 & 5.01 & 6.03 & 4.16 & 5.03 & 4.99 & 4.67 & 5.27 & 5.01 & 5.53 \\
\hline $\mathrm{CaO}$ & 4.36 & 8.97 & 6.89 & 9.20 & 9.85 & 7.61 & 6.46 & 6.34 & 5.34 & 5.90 & 6.27 & 7.85 \\
\hline $\mathrm{Na}_{2} \mathrm{O}$ & 0.91 & 4.51 & 4.20 & 4.26 & 3.03 & 4.37 & 4.62 & 5.31 & 5.07 & 5.69 & 4.52 & 5.15 \\
\hline $\mathrm{K}_{2} \mathrm{O}$ & 0.49 & 1.09 & 1.10 & 0.82 & 0.73 & 1.47 & 0.37 & 0.48 & 0.13 & 0.62 & 0.50 & 0.55 \\
\hline $\mathrm{P}_{2} \mathrm{O}_{5}$ & 0.17 & 0.27 & 0.26 & 0.26 & 0.18 & 0.27 & 0.35 & 0.28 & 0.20 & 0.41 & 0.33 & 0.02 \\
\hline LOI & 9.40 & 2.10 & 1.40 & 2.00 & 0.60 & 1.50 & 3.20 & 1.80 & 6.30 & 2.00 & 3.20 & 3.00 \\
\hline Total & 99.34 & 99.27 & 98.73 & 99.05 & 99.32 & 99.11 & 98.82 & 99.94 & 100.08 & 99.49 & 99.30 & 99.34 \\
\hline $\mathrm{Ba}$ & 175 & 410 & 425 & 301 & 309 & 376 & 282 & 189 & 34 & 229 & 362 & 248 \\
\hline $\mathrm{Rb}$ & 7 & 10 & 12 & 7 & 8 & 19 & 3 & 5 & 5 & 7 & 7 & 6 \\
\hline $\mathrm{Sr}$ & 462 & 1129 & 944 & 929 & 825 & 1113 & 771 & 725 & 232 & 1112 & 669 & 590 \\
\hline$Y$ & 7 & 14 & 12 & 15 & 15 & 16 & 16 & 22 & 17 & 23 & 25 & 17 \\
\hline $\mathrm{Zr}$ & 58 & 101 & 99 & 83 & 84 & 144 & 113 & 135 & 92 & 183 & 131 & 100 \\
\hline $\mathrm{Nb}$ & 9 & 14 & 15 & 13 & 12 & 16 & 18 & 10 & 9 & 19 & 19 & 13 \\
\hline $\mathrm{Cu}$ & 103 & 67 & 93 & 63 & 155 & 156 & 70 & 134 & 33 & 39 & 91 & 8 \\
\hline $\mathrm{Pb}$ & 767 & -- & 314 & 10 & 10 & 19 & -- & 44 & 10 & 10 & 345 & 10 \\
\hline $\mathrm{Zn}$ & 1624 & 179 & 779 & 62 & 158 & 159 & 68 & 286 & 31 & 72 & 796 & 53 \\
\hline $\mathrm{Ni}$ & 861 & 86 & 45 & 55 & 63 & 43 & 70 & 56 & 77 & 51 & 61 & 27 \\
\hline $\mathrm{Cr}$ & 826 & 209 & 43 & 131 & 11 & 26 & 136 & 136 & 187 & 145 & 127 & 93 \\
\hline V & 89 & 172 & 359 & 193 & 638 & 360 & 217 & 279 & 195 & 258 & 245 & 133 \\
\hline $\mathrm{Ga}$ & 11 & 21 & 22 & 21 & 29 & 25 & 20 & 26 & 23 & 25 & 26 & 21 \\
\hline
\end{tabular}

${ }^{1}$ Analyses by X-ray fluorescence at the Nova Scotia Regional Geochemical Centre, St. Mary's University, Halifax. Precision is about $5 \%$ for major elements and 3 to $10 \%$ for trace elements, based on replicate analyses of internal standards. Total iron is reported as $\mathrm{Fe}_{2} \mathrm{O}_{3}$. LOI is loss-on-ignition (\% weight loss after heating for one hour at $1000^{\circ} \mathrm{C}$ ).

${ }^{2}$ Sample locations and descriptions are listed in Appendix A.

shades of dark to pale brown and ranges in composition from titaniferous phlogopite (in olivine gabbro sample \#1) to biotite.

Opaque phases are a major component in some samples, forming up to $10 \%$ in sample \#5 from the St. Peters Canal gabbro. Titaniferous magnetite and ilmenite are the dominant opaque phases. The gabbro body in Toms Brook has been investigated as a possible source of magnetite (Shaw, 1988).

\section{Geochemistry}

Twenty-four samples were analyzed (Table 1; Appendix A), representing nine plutons and flows in the St. Peters area, and including the textural varieties described above. Loss-on-ignition values show wide variation, generally consistent with the degree of alteration in the samples. The highest value is $9.4 \%$ in the Quetique Island olivine gabbro (sample 1), consistent with the abundance of serpentinized olivine in the sample. Because of the variation in loss-on-ignition values, the major ele- ment oxides were recalculated to total $100 \%$ on a volatile-free basis before plotting on the diagrams discussed below.

Silica contents in all except two of the gabbro samples have a limited range in recalculated values between about 49 and $53 \%$ (Fig. 3a). The two exceptions are cumulate olivine gabbro sample \#1 from Quetique Island and opaque mineral-rich St. Peters Canal gabbro sample \#5; both are ultramafic in terms of their $\mathrm{SiO}_{2}$ contents. Because of the limited variation in silica in the sample suite as a whole, the $\mathrm{FeO}^{\mathrm{t}} / \mathrm{MgO}$ ratio is used as the $x$-axis on variation diagrams (Figs. 3, 4, 5). This ratio ranges from 0.6 to 2.8, and hence is better than $\mathrm{SiO}_{2}$ for revealing chemical trends among the samples.

Excluding the anomalous gabbro samples 1 and 5 noted above, $\mathrm{Al}_{2} \mathrm{O}_{3}, \mathrm{MgO}, \mathrm{Ni}$, and $\mathrm{Cr}$ show negative correlation with $\mathrm{FeO} / \mathrm{MgO}$ ratio (Figs. 3, 4), whereas $\mathrm{TiO}_{2}$, $\mathrm{FeO}$,, $\mathrm{V}$ (Fig. 5), and $\mathrm{Cu}$ (not shown) show positive correlation. The trend in $\mathrm{Ni}$ tends to flatten in samples with $\mathrm{FeO} / \mathrm{MgO}$ more than about 2 . $\mathrm{Na}_{2} \mathrm{O}$ (Fig. 5), as well as $\mathrm{CaO}, \mathrm{K}_{2} \mathrm{O}, \mathrm{Sr}, \mathrm{Ba}$, and $\mathrm{Rb}$ (plots not 
Table 1 continued.

\begin{tabular}{|c|c|c|c|c|c|c|c|c|c|c|c|c|}
\hline & 13 & 14 & 15 & 16 & 17 & 18 & 19 & 20 & 21 & 22 & 23 & 24 \\
\hline $\mathrm{SiO}_{2}$ & 49.37 & 49.95 & 47.53 & 49.49 & 47.34 & 47.26 & 48.72 & 49.36 & 50.90 & 47.85 & 48.61 & 47.48 \\
\hline $\mathrm{TiO}_{2}$ & 2.73 & 2.35 & 2.68 & 2.42 & 2.28 & 2.24 & 1.98 & 2.20 & 2.28 & 1.87 & 2.23 & 2.28 \\
\hline $\mathrm{Al}_{2} \mathrm{O}_{3}$ & 14.91 & 15.50 & 14.86 & 15.15 & 14.80 & 15.02 & 16.92 & 15.71 & 16.09 & 16.72 & 14.48 & 15.74 \\
\hline $\mathrm{Fe}_{2} \mathrm{O}_{3}$ & 12.61 & 10.80 & 11.31 & 11.10 & 10.73 & 10.97 & 9.92 & 10.77 & 8.22 & 11.28 & 11.88 & 11.20 \\
\hline $\mathrm{MnO}$ & 0.20 & 0.15 & 0.48 & 0.16 & 0.15 & 0.19 & 0.12 & 0.15 & 0.11 & 0.18 & 0.09 & 0.19 \\
\hline $\mathrm{MgO}$ & 5.78 & 6.30 & 4.75 & 5.98 & 6.42 & 6.66 & 6.26 & 6.60 & 6.91 & 7.22 & 5.46 & 5.41 \\
\hline $\mathrm{CaO}$ & 6.51 & 6.77 & 7.60 & 6.57 & 7.49 & 7.54 & 6.62 & 6.86 & 6.66 & 5.57 & 6.62 & 8.21 \\
\hline $\mathrm{Na}_{2} \mathrm{O}$ & 4.24 & 4.32 & 5.49 & 4.73 & 4.57 & 3.67 & 3.78 & 4.07 & 4.62 & 3.02 & 5.49 & 4.08 \\
\hline $\mathrm{K}_{2} \mathrm{O}$ & 0.72 & 1.02 & 0.28 & 0.78 & 0.31 & 0.34 & 1.04 & 0.42 & 0.31 & 2.20 & 0.57 & 0.75 \\
\hline $\mathrm{P}_{2} \mathrm{O}_{5}$ & 0.30 & 0.27 & 0.32 & 0.32 & 0.29 & 0.28 & 0.28 & 0.21 & 0.17 & 0.92 & 0.39 & 0.34 \\
\hline LOI & 1.80 & 2.00 & 4.00 & 2.60 & 5.20 & 4.90 & 2.70 & 2.00 & 2.00 & 4.10 & 4.70 & 2.80 \\
\hline Total & 99.17 & 99.43 & 99.32 & 99.30 & 99.07 & 99.07 & 98.34 & 98.35 & 98.27 & 100.93 & 100.52 & 98.48 \\
\hline $\mathrm{Ba}$ & 240 & 290 & 249 & 280 & 206 & 220 & 282 & 130 & 56 & 1378 & 180 & 240 \\
\hline $\mathrm{Rb}$ & 10 & 15 & 3 & 7 & 5 & 5 & 20 & 7 & 5 & 35 & 10 & 9 \\
\hline $\mathrm{Sr}$ & 828 & 773 & 675 & 642 & 655 & 710 & 735 & 709 & 665 & 1179 & 372 & 797 \\
\hline$Y$ & 21 & 16 & 16 & 15 & 18 & 17 & 18 & 18 & 19 & 30 & 21 & 17 \\
\hline $\mathrm{Zr}$ & 108 & 106 & 126 & 118 & 124 & 99 & 125 & 125 & 108 & 323 & 137 & 127 \\
\hline $\mathrm{Nb}$ & 17 & 14 & 16 & 14 & 14 & 12 & 12 & 9 & 12 & 30 & 18 & 14 \\
\hline $\mathrm{Cu}$ & 70 & 57 & 46 & 138 & 6 & 34 & 53 & 43 & 12 & 16 & 63 & 60 \\
\hline $\mathrm{Pb}$ & 75 & -- & 623 & -- & 10 & 10 & 47 & 10 & 10 & 13 & 6 & 23 \\
\hline $\mathrm{Zn}$ & 268 & 113 & 2069 & 112 & 105 & 84 & 177 & 107 & 107 & 289 & 132 & 145 \\
\hline $\mathrm{Ni}$ & 60 & 81 & 62 & 146 & 157 & 172 & 144 & 124 & 87 & 185 & 44 & 92 \\
\hline $\mathrm{Cr}$ & 110 & 165 & 139 & 281 & 260 & 261 & 221 & 223 & 184 & 185 & 159 & 176 \\
\hline V & 233 & 199 & 242 & 209 & 204 & 193 & 161 & 200 & 181 & 169 & 149 & 190 \\
\hline $\mathrm{Ga}$ & 23 & 21 & 19 & 19 & 23 & 19 & 21 & 22 & 20 & 22 & 20 & 23 \\
\hline
\end{tabular}

shown), do not show any significant correlation with $\mathrm{FeO} / \mathrm{MgO}$, and their scatter may partly reflect the alteration apparent in thin section. $\mathrm{P}_{2} \mathrm{O}_{5}$ shows a peak at about $\mathrm{FeO} / \mathrm{MgO}=2$, and then decreases, probably reflecting apatite fractionation (Fig. 4). In general, no consistent chemical differences are apparent among plutons or textural varieties, other than a tendency for fine-grained samples to have lower $\mathrm{K}_{2} \mathrm{O}, \mathrm{Rb}$, and $\mathrm{Ba}$ than medium- to coarse-grained samples, perhaps a result of more intense alteration (Fig. 6a). The chemical trends in the gabbroic suite are consistent with a major role for $\mathrm{Mg}$-rich olivine and pyroxene fractionation. The increase in $\mathrm{FeO}^{\mathrm{t}}, \mathrm{V}$ and $\mathrm{TiO}_{2}$ with $\mathrm{FeO} / \mathrm{MgO}$ ratio shows that minerals such as magnetite and ilmenite were not being removed by fractionation processes.

Olivine gabbro sample \#1, in addition to having low $\mathrm{SiO}_{2}$ content, also has the lowest $\mathrm{FeO} / \mathrm{MgO}$ and $\mathrm{TiO}_{2}, \mathrm{Al}_{2} \mathrm{O}_{3}, \mathrm{CaO}$, $\mathrm{Na}_{2} \mathrm{O}, \mathrm{V}, \mathrm{Zr}$, and $\mathrm{Y}$ contents, and the highest $\mathrm{MgO}, \mathrm{FeO}^{\mathrm{t}}, \mathrm{Ni}$, $\mathrm{Cr}$, and $\mathrm{Zn}$ (Fig. 6b), and is also relatively high in $\mathrm{MnO}$ and $\mathrm{Cu}$. Its low $\mathrm{FeO} / \mathrm{MgO}$ and correspondingly high $\mathrm{Mg \#}(\mathrm{Mg} /$ $\mathrm{Mg}+\mathrm{Fe}=74$ ), as well as high $\mathrm{Ni}$ and $\mathrm{Cr}$ contents, are consistent with its interpretation as a cumulate, and hence not representative of a magmatic composition; primary mantle-derived melts have $\mathrm{Mg \#}$ about 66, and $\mathrm{Cr}$ and $\mathrm{Ni}$ about 300 ppm (Basaltic Volcanism Study Project, 1981).

Basalt sample \#11 from MacLeans Point is chemically simi- lar to the gabbros (Fig. 6b). However, basalt sample \#22 from Chapel Island shows some large chemical differences compared to the gabbros, in particular high $\mathrm{K}_{2} \mathrm{O}, \mathrm{P}_{2} \mathrm{O}_{5}, \mathrm{Rb}, \mathrm{Ba}, \mathrm{Y}, \mathrm{Zr}$, and $\mathrm{Nb}$ contents (Fig. $6 \mathrm{~b}$ ). More sampling is required in order to test investigate the significance of these differences.

Relatively high $\mathrm{Na}_{2} \mathrm{O}$ contents in the St. Peters gabbros led previous workers to suggest that the suite is alkalic (Davis, 1972; Durocher, 1974; Keppie and Smith, 1978). However, the extent of albitization in the plagioclase evident in microprobe analyses (Grammatikopoulos, 1992) suggests that the rocks may have experienced sodic metasomatism, and hence that alkali elements are not likely to be reliable indicators of chemical affinity. Multi-element variation diagrams (Fig. 6a) show scatter in the more mobile incompatible elements, but much less variation in the typically less mobile elements $\mathrm{Nb}, \mathrm{P}_{2} \mathrm{O}_{5}, \mathrm{Zr}$, and $\mathrm{TiO}_{2}$. As discussed above, the variations in $\mathrm{Cr}$ and $\mathrm{Ni}$ can be attributed to fractional crystallization processes within the gabbroic magmas. The average abundances for $\mathrm{Nb}, \mathrm{P}_{2} \mathrm{O}_{5}, \mathrm{Zr}$, and $\mathrm{TiO}_{2}$ are similar to those in the average within-plate tholeiite of Pearce (1982), and lower than those in the average alkalic basalt. However, $\mathrm{V}$ contents of the gabbros are more similar to those in the average alkalic basalt, as are their V/Ti values of more than 50 (Shervais, 1977). Low Y values are also characteristic of the samples, averaging $17 \mathrm{ppm}$, compared to values 


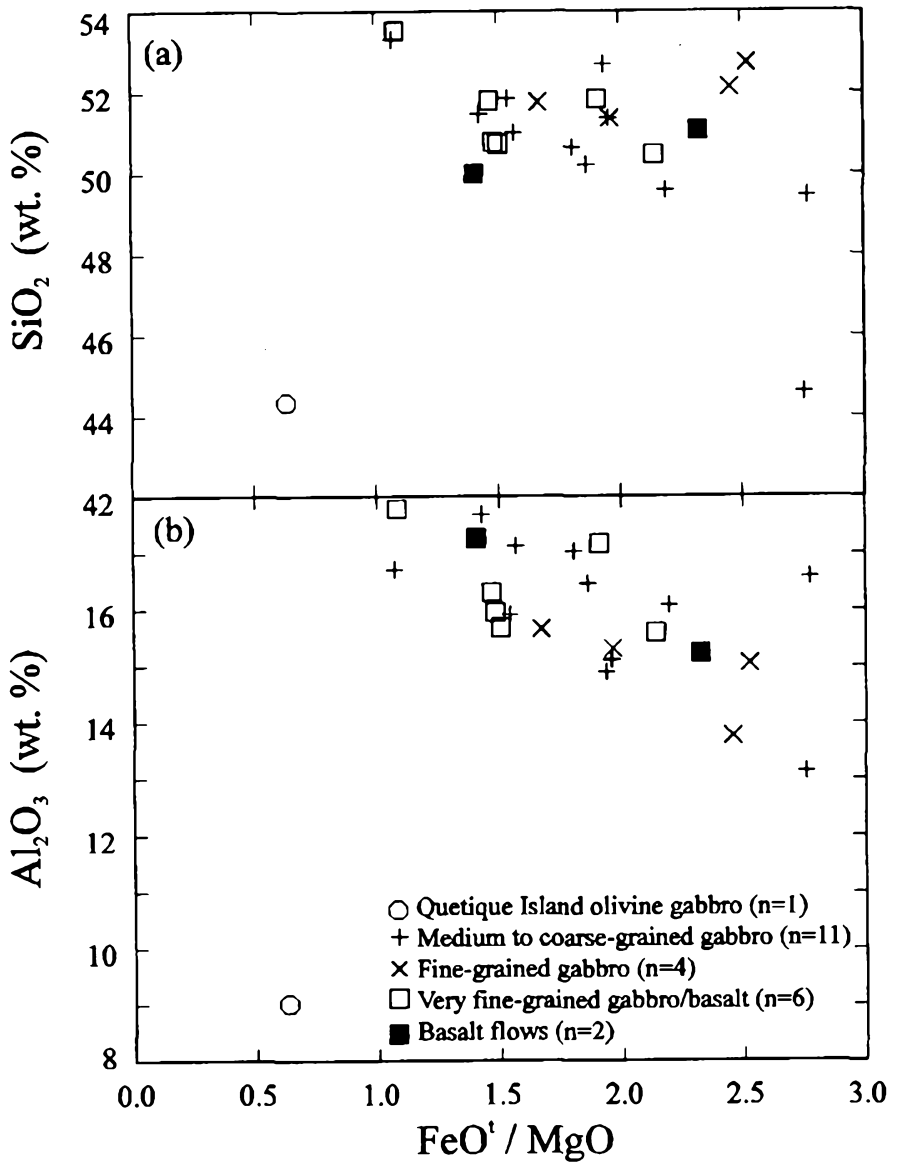

Fig. 3. Plots of $\mathrm{SiO}_{2}$ and $\mathrm{Al}_{2} \mathrm{O}_{3}$ against $\mathrm{FeO}^{\mathrm{t}} / \mathrm{MgO}$.

of 26 and 25 cited by Pearce (1982) for within-plate tholeiitic and within-plate alkalic basalts, respectively.

On the Ti-Zr-Y diagram (Fig. 7a), the St. Peters samples plot mainly in the within-plate field, with a spread toward higher Ti values; their position also reflects the low $\mathrm{Y}$ contents in most samples. On the $\mathrm{Nb}-\mathrm{Zr}-\mathrm{Y}$ diagram (Fig. 7b), they plot almost entirely in the field for both within-plate tholeiitic and withinplate alkalic basalts.

Four samples analyzed for rare-earth elements (Table 2) show relative enrichment in light REE compared to the heavy REE, with light REE about 20 to 30 times chondritic values, and heavy REE 2 to 5 times chondritic values (Fig. 8). Olivine gabbro sample 1 has the lowest absolute REE abundances (Table 2). The other three samples $(3,5$ and 4$)$ have almost identical chondrite-normalized patterns and all of the samples show a slight positive Eu anomaly, consistent with other chemical data discussed above which indicate that plagioclase was not an important fractionating phase. The degree of light REE enrichment is similar to that for continental within-plate tholeiitic suites such as Columbia Plateau, and less than that for typical within-plate alkalic suites such as that of the Gregory Rift in East Africa (Fig. 8). The Ta and $\mathrm{Hf}$ values in these four samples (average 2.0 and $0.84 \mathrm{ppm}$, respectively; Table 2) are also more similar to the values for within-plate tholeiitic basalts (average 3.44 and $0.73 \mathrm{ppm}$, respectively; Pearce, 1982) than those for within-plate alkalic basalts (average 6.36 and $5.9 \mathrm{ppm}$, respectively; Pearce, 1982). Overall, tholeiitic affinity seems more likely than alkalic on the basis of these elements.

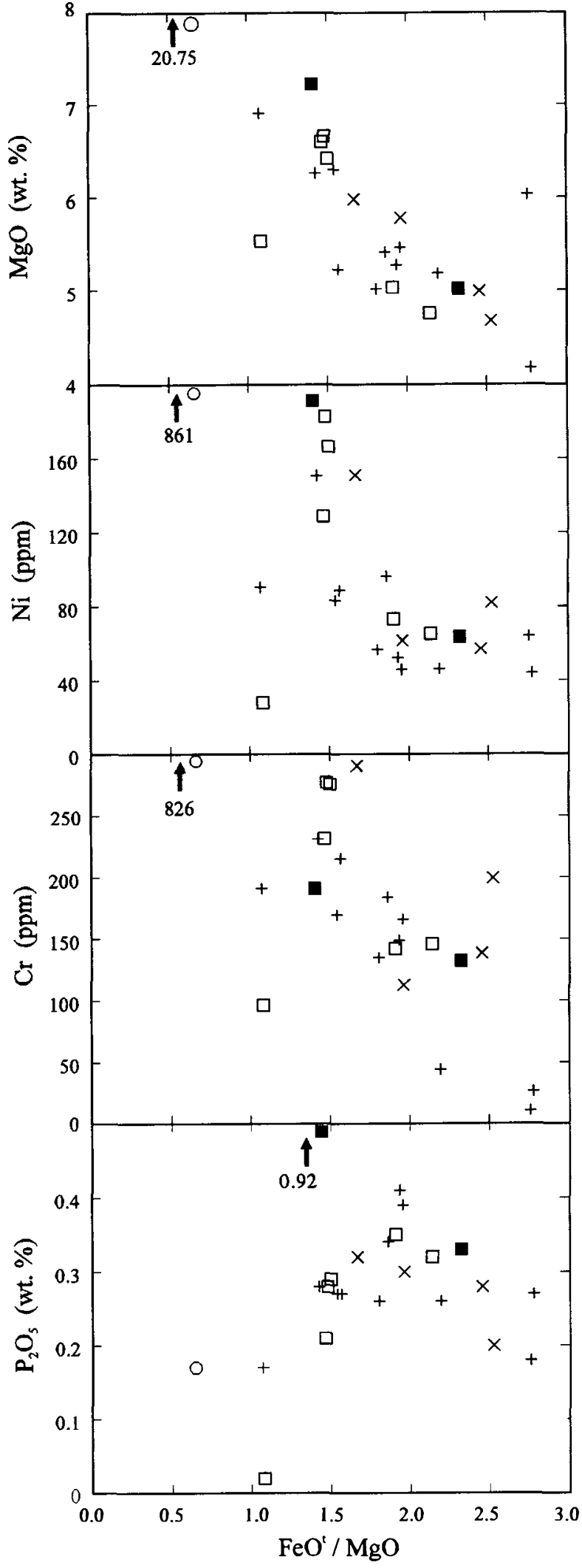

Fig. 4. Plots of $\mathrm{MgO}, \mathrm{Ni}, \mathrm{Cr}$, and $\mathrm{P}_{2} \mathrm{O}_{5}$ against $\mathrm{FeO} / \mathrm{MgO}$.

However, the St. Peters gabbros differ from both continental tholeiitic and alkalic suites in their low abundance of heavy REE (Fig. 8). One possible explanation for this relative depletion in heavy REE may be the presence of garnet, which has very large mineral/melt distribution coefficient values for heavy 


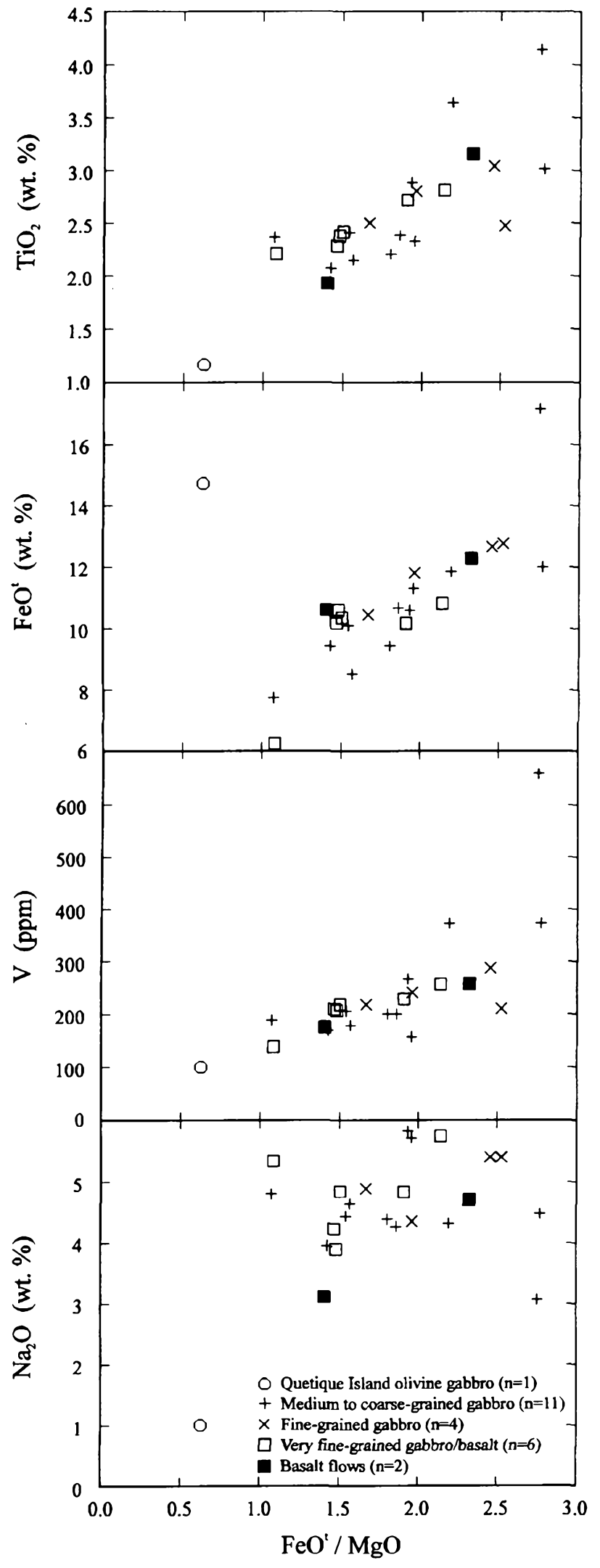

Fig. 5. Plots of $\mathrm{TiO}_{2}, \mathrm{FeO}^{\mathrm{t}}, \mathrm{V}$, and $\mathrm{Na}_{2} \mathrm{O}$ against $\mathrm{FeO}^{\mathrm{t}} / \mathrm{MgO}$.

REE (Hanson, 1980), in the residue left by partial melting. Hence, it is suggested that the source for the gabbro magmas may have been garnet peridotite, rather than spinel peridotite which is the source of many mafic magmas.

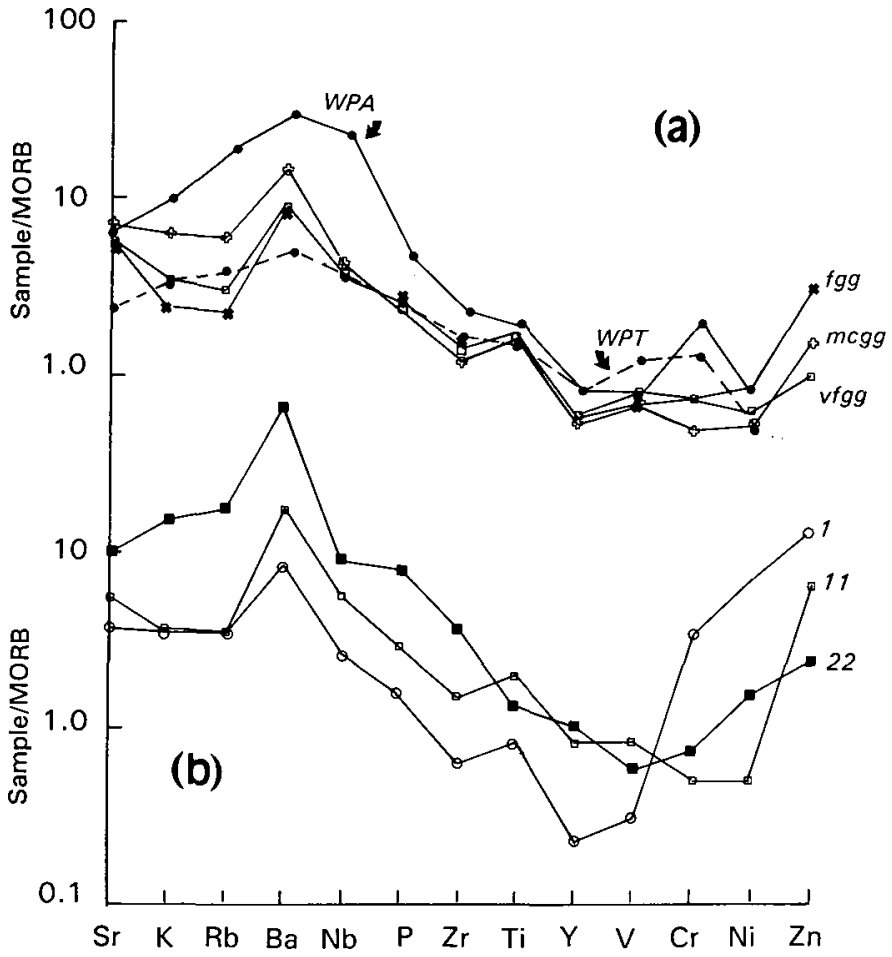

Fig. 6. (a) Multi-element variation diagrams for average medium- to coarse-grained gabbro ( $\mathrm{mcgg}$ ), fine-grained gabbro ( $\mathrm{fgg}$ ), and very finegrained gabbro/basalt (Vfgg) from the St. Peters samples, compared to average within-plate tholeiitic (WPT) and alkalic (WPA) basalts from Pearce (1982). Data are normalized against average mid-ocean ridge basalt from Pearce (1982). (b) Similar diagram for other samples 1 (olivine gabbro), 11 (MacLean Point basalt), and 22 (Chapel Island basalt).

In summary, the petrochemical data combined with geological setting indicate that the gabbros formed in a continental within-plate environment. Although their characterization as tholeiitic or alkalic is not definitive, most data suggest tholeiitic affinity.

\section{U-PB DATING}

The sample for $\mathrm{U}-\mathrm{Pb}$ dating was collected from a more felsic pegmatoid area in the St. Peters Canal gabbro near its faulted southern contact with sedimentary rocks of the Horton Group. The sample is very coarse-grained and consists of a network of large saussuritized plagioclase crystals up to $2 \mathrm{~cm}$ in length, with interstitial green-brown amphibole and biotite. Accessory apatite, titanite, and ilmenite are abundant.

Zircon and baddeleyite were obtained from the bulk crushed rock sample using a Wilfley table and further concentrated using a combination of heavy liquids and magnetic separation. Mineral separates were hand-picked under a microscope to obtain high quality, morphologically similar grains. Zircon fractions were abraded using the technique of Krogh.(1982). Analytical methods were as described by Dunning et al. (1990). Regression lines were calculated using the program of Davis (1982), and uncertainties on the ages are reported at the $95 \%$ confidence level.

Three zircon and three baddeleyite fractions were analyzed (Table 3; Fig. 9). All exhibit slight Pb loss; a line (12.6\% prob- 

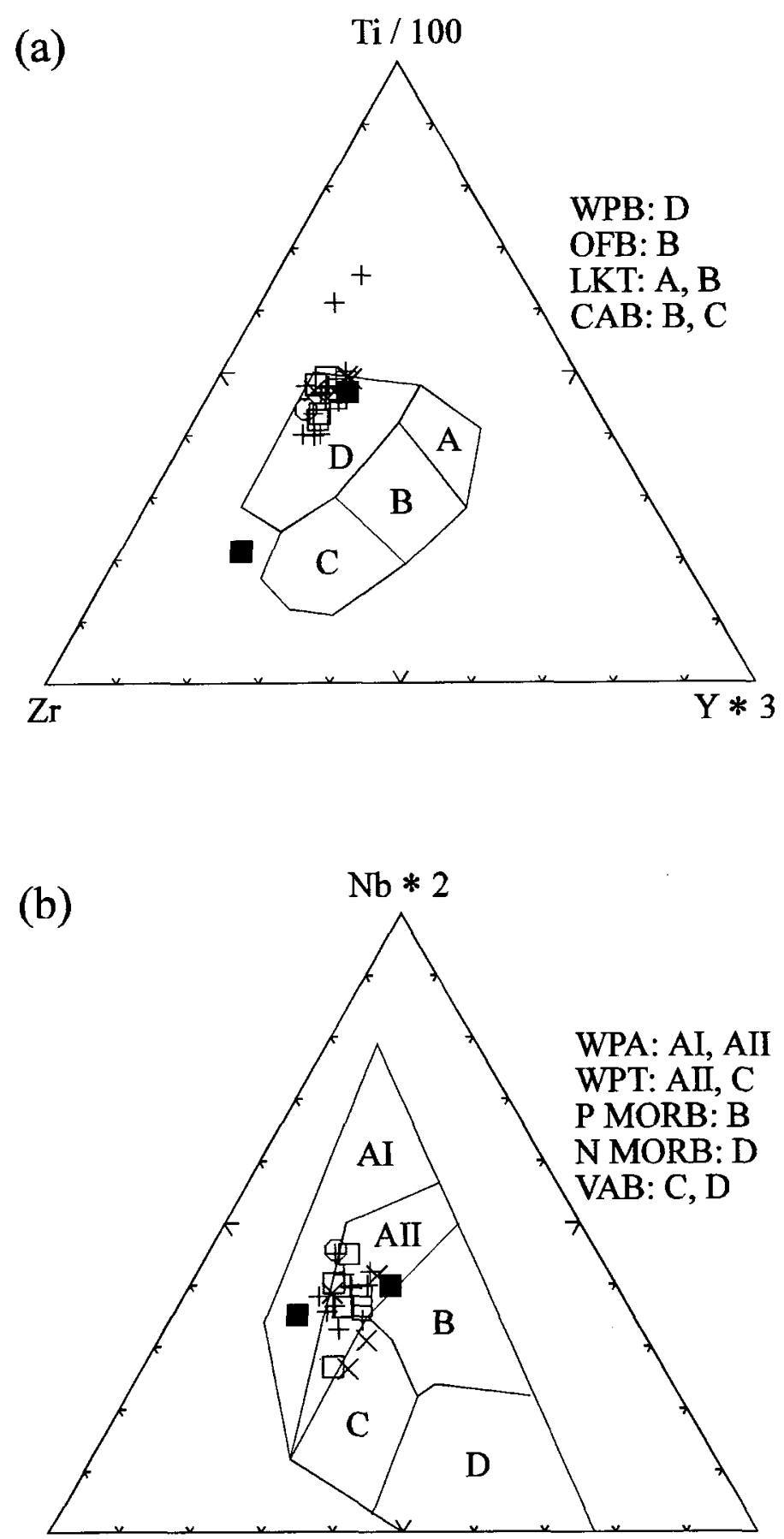

$\mathrm{Zr} / 4$

Fig. 7. Ternary plots of (a) Ti-Zr-Y (fields from Pearce and Cann, 1973) and (b) Nb-Zr-Y (fields from Meschede, 1986) for samples from the St. Peters area. Abbreviations: WPB $=$ within-plate basalt, $\mathrm{OFB}=$ ocean floor basalt, $\mathrm{LKT}=$ low-potassium tholeiite, $\mathrm{CAB}=$ calc-alkalic basalt, WPA $=$ within-plate alkalic basalt, WPT $=$ within-plate tholeiitic basalt, $\mathrm{P}-\mathrm{MORB}=$ primitive mid-ocean ridge basalt, $\mathrm{N}-\mathrm{MORB}=$ normal mid-ocean ridge basalt, $\mathrm{VAB}=$ volcanic-arc basalt.

ability of fit) through all 6 fractions indicates an age of $341+3 /$ $-2 \mathrm{Ma}$. The three zircon fractions define a line $(97 \%$ probability of fit) with an upper intercept age of $339 \pm 2 \mathrm{Ma}$. The latter age is considered to be more reliable because of the apparent tendency for baddeleyite to give ages marginally older than zircon ages. The age of $339 \pm 2 \mathrm{Ma}$ is within the error range of the $\mathrm{K}$ Ar (biotite) age of $347 \pm 36 \mathrm{Ma}$ reported by Wanless et al. (1979).
Table 2. Rare-earth element and Hf, Ta, and Sc data for four samples from the St. Peters gabbros.

\begin{tabular}{lrrrr}
\hline & & & & \\
Element & \multicolumn{1}{c}{1} & \multicolumn{1}{c}{3} & \multicolumn{1}{c}{5} & 14 \\
& & & & \\
\hline & & & & \\
La & 7.67 & 10.04 & 8.38 & 9.96 \\
$\mathrm{Ce}$ & 17.25 & 22.68 & 19.98 & 23.19 \\
$\mathrm{Pr}$ & 2.26 & 3.27 & 2.85 & 3.37 \\
$\mathrm{Nd}$ & 10.36 & 15.62 & 14.10 & 16.29 \\
$\mathrm{Sm}$ & 2.33 & 4.04 & 3.85 & 4.36 \\
$\mathrm{Eu}$ & 0.87 & 1.56 & 1.49 & 1.66 \\
$\mathrm{Gd}$ & 2.22 & 3.86 & 3.86 & 4.22 \\
$\mathrm{~Tb}$ & 0.27 & 0.53 & 0.48 & 0.64 \\
$\mathrm{Dy}$ & 1.55 & 2.73 & 2.71 & 3.33 \\
$\mathrm{Ho}$ & 0.26 & 0.47 & 0.46 & 0.58 \\
$\mathrm{Er}$ & 0.66 & 1.18 & 1.19 & 1.48 \\
$\mathrm{Tm}$ & 0.09 & 0.15 & 0.14 & 0.15 \\
$\mathrm{Yb}$ & 0.56 & 0.88 & 0.89 & 1.18 \\
$\mathrm{Lu}$ & 0.07 & 0.12 & 0.12 & 0.16 \\
$\mathrm{Hf}$ & 1.30 & 2.09 & 2.08 & 2.51 \\
$\mathrm{Ta}$ & 0.68 & 0.71 & 1.10 & 0.85 \\
$\mathrm{Sc}$ & 12.91 & 21.82 & 37.37 & 17.62 \\
& & & & \\
\hline
\end{tabular}

\footnotetext{
${ }^{1}$ Analyses by ICP-MS, Department of Earth Sciences, Memorial University.
}

\section{Discussion}

The location of the St. Peters gabbros along the Lennox Passage - St. Peters lineament suggests that their origin can be broadly related to the development of the Maritimes Basin. The lineament has been traced to the northeast and offshore (Jansa et al., 1993), but postulated mergence with other major faults to the southwest (Fig. 1) is not yet confirmed.

Based on the U-Pb age presented above, the St Peters gabbros are younger than volcanic rocks of the Fisset Brook Formation in central and northern Cape Breton Island (Fig. 1), for which a mid- to Late Devonian age is generally accepted, based on fossil evidence from associated sedimentary units (Smith and Macdonald, 1981; Dostal et al., 1983; Blanchard et al., 1984), and recent U-Pb dating (Barr et al., in press; D.J.W. Piper, personal communication, 1995). However, an Early Carboniferous age has also been suggested for the Fisset Brook Formation, based on Rb-Sr dates (e.g., Cormier and Kelley, 1964; Kelley and Mackasey, 1965; Huard, 1984). Mafic dykes are known to have intruded sedimentary rocks assigned to the Horton Group overlying the Fisset Brook Formation in the southern Creignish Hills (MacDougall, 1994), and these gabbroic dykes could be similar in age to the St. Peters gabbros. Like the St. Peters gabbros, the mafic volcanic rocks of the Fisset Brook Formation, as well as the younger mafic dykes in the southern Creignish Hills, appear to be mainly within-plate tholeiites (Dostal et al., 1983; Blanchard et al., 1984; MacDougall, 1994; Arnott, 1994). They have been interpreted to represent localized extension and basin development associated with the opening of the Magdalen Basin (e.g., Bradley, 1982). 


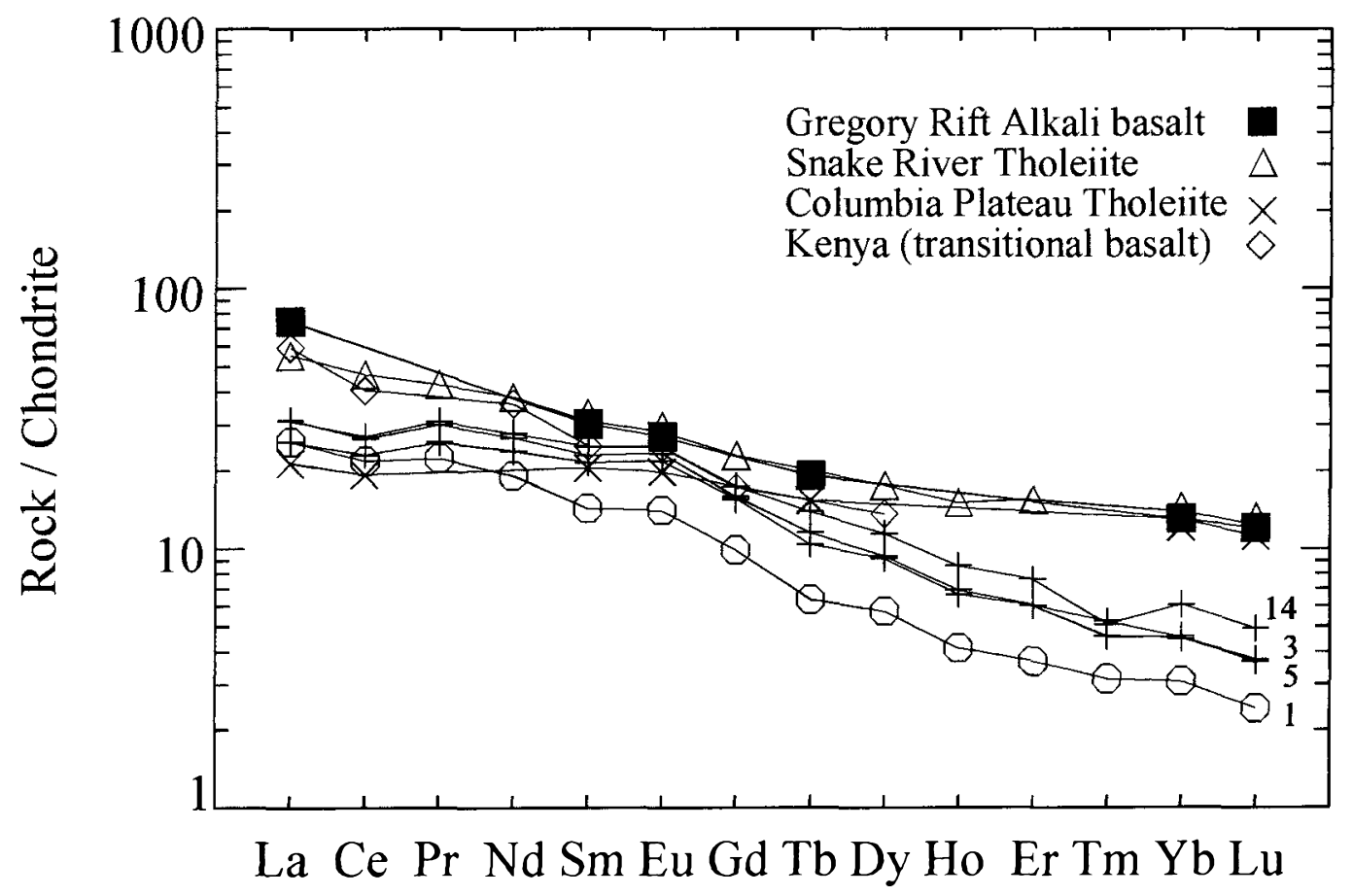

Fig. 8. Chondrite-normalized rare-earth element plot for coarse-grained gabbro samples 3, 5, and 14 and olivine gabbro sample 1. Patterns for within-plate continental tholeiitic basalt from the Columbia Plateau in the USA and alkalic basalt from the Gregory rift in East Africa (data from Wilson, 1989) are shown for comparison. Chondrite normalizing values are from Evensen et al. (1978).

Previous workers have inferred a correlation between the St. Peters gabbros and gabbroic rocks in the Guysborough area of northern mainland Nova Scotia (e.g., Geological Map of Nova Scotia, 1965; Durocher, 1974). Cormier (1994) showed that many of these "gabbroic plutons" on older maps are volcanic, and include both basalt and rhyolite flows and tuffs. One of the rhyolite units yielded a U-Pb (zircon) age of $c a$. $389 \mathrm{Ma}$ (G. Dunning, unpublished data, 1994), and hence the volcanic rocks in the Guysborough area appear to be significantly older than the gabbroic plutons of the St. Peters area. However, it is possible that some small gabbroic plutons in the Guysborough area are not the same age as the volcanic rocks in the area (Cormier, 1994); dating is in progress to determine the age of one of the Guysborough gabbros to see if it might be the same age as the St. Peters gabbros.

Farther west in the Cobequid Highlands, granitic plutons closely associated with gabbroic plutons appear to be about 20 $\mathrm{Ma}$ older than the St. Peters gabbros, based on U-Pb data which indicate ages of ca. $360 \mathrm{Ma}$ or more (Doig et al., 1991; Piper et al., 1993), and preliminary U-Pb data from volcanic rocks of the spatially associated Fountain Lake Group appear to be of similar ca. 360 Ma age (D.J.W. Piper, personal communication, 1995). Parts of the Fountain Lake Group has been interpreted previously to be of similar age to the St. Peters gabbros, based on Rb-Sr dating (Piper et al., 1993), but the validity of these ca. $340 \mathrm{Ma} \mathrm{Rb}-\mathrm{Sr}$ "isochron ages" is uncertain. Similar $\mathrm{Rb}-\mathrm{Sr}$ "ages" also have been obtained from rhyolite and basalt in the Guysborough area (R.F. Cormier, cited by Cormier, 1994), and in the Fisset Brook Formation (Huard, 1984), but do not appear to represent the crystallization ages of the rocks. On the basis of current data, it seems that none of these other plutonic and volcanic units are as young as the St. Peters gabbros.
In New Brunswick, minor mafic volcanic rocks of Early Carboniferous age have been reported from several areas, with ages reasonably well constrained by stratigraphic evidence but not yet by radiometric dating (Fyffe and Barr, 1986). Like the St. Peters gabbros, these volcanic rocks appear to be mainly tholeiitic in composition (Fyffe and Barr, 1986). In contrast, younger mafic volcanic rocks at scattered locations in New Brunswick, as well as in the Magdalen Islands, appear to be mainly alkalic (Barr et al., 1985; Fyffe and Barr, 1986). Fyffe and Barr (1986) attributed these variations to a decrease in the rate of extension in the Maritimes Basin between the Visean and Namurian.

In conclusion, the data presented here confirm an Early Carboniferous (Visean) age for the St. Peters gabbros and show that they formed in a within-plate (extensional) tectonic setting. More detailed tectonic interpretations and comparison of the St. Peters gabbros with other igneous rocks of similar age in the region awaits more detailed information about the overall age distribution of mid-Devonian to Carboniferous igneous activity in the Maritimes Basin.

\section{ACKNOWLEDGEMENTS}

This paper is based in part on a petrological study done by the second author as part of his M.Sc. thesis project at Acadia University. That work was funded by a Research Grant to SMB from the Natural Sciences and Engineering Research Council. A contribution to the cost of $\mathrm{U}-\mathrm{Pb}$ dating was made through a contract to SMB supported by the Geological Survey of Canada through the 1992-1996 Canada - Nova Scotia Cooperation Agreement on Mineral Development. We thank the reviewers, L.R. Fyffe and D.J.W. Piper, and editor G.L. Williams for their helpful comments which led to improvments in the manuscript. 


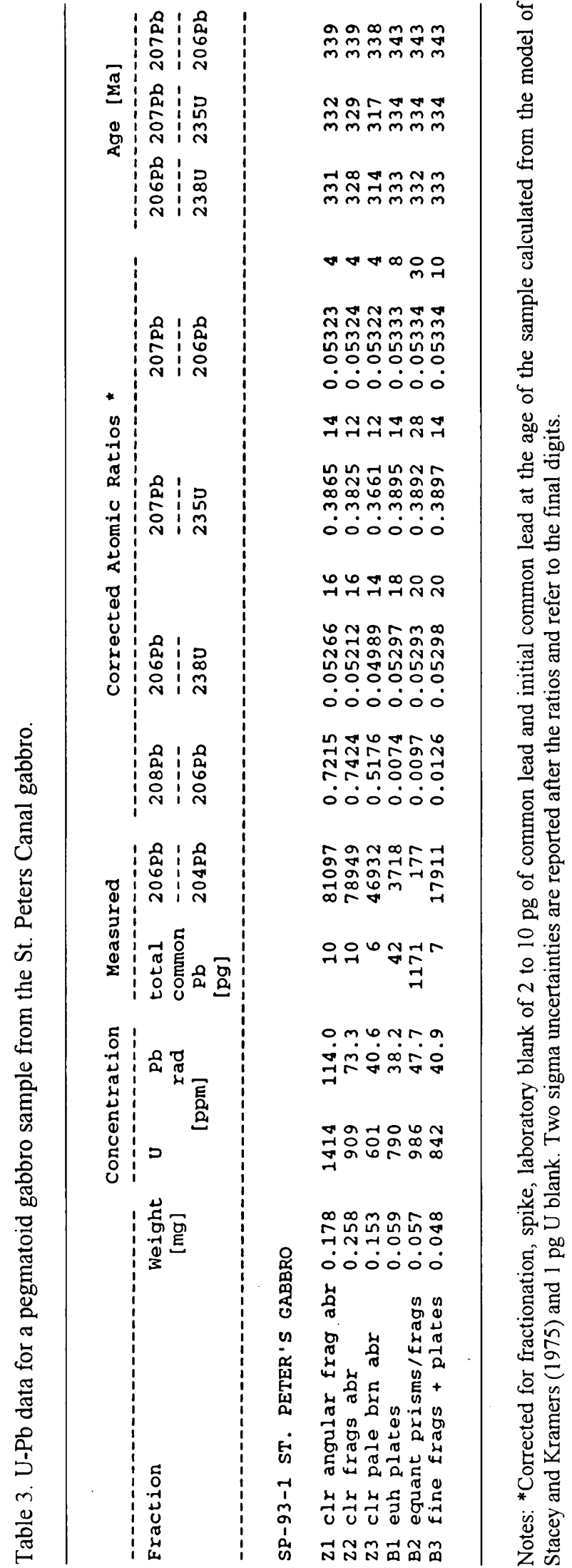

ARnort, A. 1994. Petrology and geochemistry of the Fisset Brook Formation in the Gillanders Mountain area, Cape Breton Island, Nova Scotia. Unpublished B.Sc. thesis, Acadia University, Wolfville, Nova Scotia.

Barr, S.M., Cormier, C.F.M., White, C.E., and Dunning, G.R. In press. Devonian - Carboniferous volcanic and gabbroic rocks in

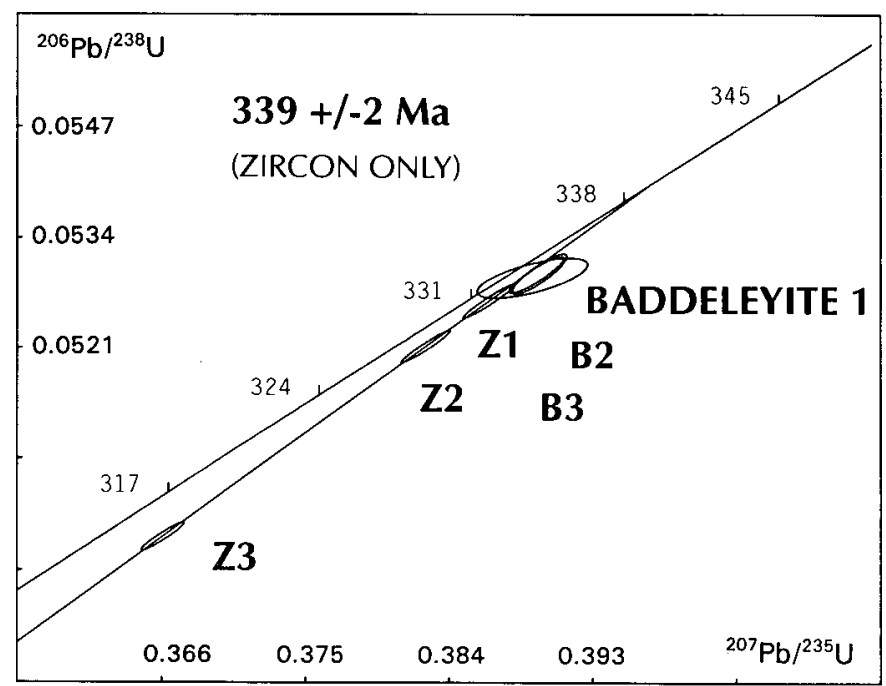

Fig. 9. Concordia plot for data in Table 3.

Guysborough County and Cape Breton Island, Nova Scotia. Atlantic Geoscience Society Annual Colloquium, Antigonish, Nova Scotia, February 3-4, 1995. Abstract in Atlantic Geology, 31.

Barr, S.M., Brisebois, D., and Macdonald, A.S. 1985. Carboniferous volcanic rocks of the Magdalen Islands, Gulf of St. Lawrence. Canadian Journal of Earth Sciences, 22, pp. 1679-1688.

Basaltic Volcanism Study Project 1981. Basaltic volcanism on the terrestrial planets. Pergamon Press, Inc., New York, New York, $1286 \mathrm{p}$.

Blanchard, M., Jamieson, R.A., and More, E.B. 1984. Late Devonian - Early Carboniferous volcanism in western Cape Breton Island, Nova Scotia. Canadian Journal of Earth Sciences, 21, pp. $762-$ 774 .

Bradley, D.C. 1982. Subsidence in Late Paleozoic basins in the northern Appalachians. Tectonics, 1, pp. 107-123.

CORMIER, C.F.A. 1994. Field relations, petrology, and age of volcanic and associated sedimentary and gabbroic rocks in the Guysborough area, Nova Scotia. Unpublished M.Sc. thesis, Acadia University, Wolfville, Nova Scotia, 58 p.

Cormier, R.F. and Kelly, A.M. 1964. Absolute age of the Fisset Brook Formation and the Devonian-Mississippian Boundary, Cape Breton Island, Nova Scotia. Canadian Journal of Earth Sciences, 1, pp. 159-166.

DaVIs, J.L. 1972. The petrography and petrochemistry of mafic rocks in the Chedabucto - St. Peter's Bay area. M.Eng. thesis, Technical College, Halifax, Nova Scotia, 168 p.

Davis, D.W. 1982. Optimum linear regression and error estimation applied to U-Pb data. Canadian Journal of Earth Sciences, 19, pp. 2141-2149.

Dolg, R., Murphy, J.B., Nance, R.D., and Stokes, T. 1991. Review of the geochronology of the Cobequid Highlands, Avalon Composite Terrane, Nova Scotia. In Current Research, Part D, Geological Survey of Canada, Paper 91-1D, pp. 71-78.

Donohoe, H.V., JR. and Grantham, R.G. 1989. Geological Highway Map of Nova Scotia, second edition. Atlantic Geoscience Society, Special Publication Number 1.

Dostal, J., Keppie, J.D., and Dupuy, C. 1983. Petrology and geochemistry of Devono-Carboniferous volcanic rocks in Nova Scotia. Maritime Sediments and Atlantic Geology, 19, pp. 59-71.

Douglas, G.V. and Goodman, N.R. 1940. Manganese, Hay Cove, Richmond County, Nova Scotia; geological report of Toms Brook area (Hay Cove). Nova Scotia Department of Mines and Energy, Assessment Report 11F/10D 31-O-07(01) 
Dunning, G.R., O'Brien, S.J., Colman-Sadd, S.P., Blackwood, R.F., DICKson, W.L., O'NeILL, P.P., and KROGH, T.E. 1990. Silurian orogeny in the Newfoundland Appalachians. Journal of Geology, 98, pp. 895-913.

DUROCHER, A.C. 1974. Basic magmatism in Nova Scotia. Unpublished M.Sc. thesis, Acadia University, Wolfville, Nova Scotia, 129 p.

Evensen, N.M., Hamilton, P.J., and O'Nions, R.K. 1978. Rare-earth abundances in chondritic meteorites. Geochimica et Cosmochimia Acta, 42, pp. 1199-1212.

FYFFE, L.R. and BARR, S.M. 1986. Petrochemistry and tectonic significance of Carboniferous volcanic rocks in New Brunswick. Canadian Journal of Earth Sciences, 23, pp. 1243-1256.

Geological Map of Nova Scotia 1965. Nova Scotia Department of Mines, Scale 1:506,880.

Grammatikoporros, A. 1992. Petrogenesis, age and economic potential of gabbroic plutons in the Avalon Terrane in southern New Brunswick and southeastern Cape Breton Island. M.Sc. thesis, Acadia University, Wolfville, Nova Scotia, 378 p.

Hanson, G.N. 1980. Rare earth elements in petrogenetic studies of igneous systems. Annual Review of Earth Planetary Science, 8, pp. $371-406$.

HUARD, A.A. 1984. The Carboniferous volcanic rocks at Lake Ainslie, Nova Scotia: implications for tectonic regime and barite mineralization. B.Sc. thesis, St. Francis Xavier University, Antigonish, Nova Scotia, 72 p.

Jansa, L.F., Pe-PiPer, G., and Loncarevic, B.D. 1993. Appalachian basement and its intrusion by Cretaceous dykes, offshore southeast Nova Scotia, Canada. Canadian Journal of Earth Sciences, 30, pp. 2495-2509.

Kelley, D.G. and Mackasey, W.O. 1965. Basal Mississippian volcanic rocks in Cape Breton Island, Nova Scotia. Geological Survey of Canada, Paper 64-34.

KEPPIE, J.D. 1979. Geological map of Nova Scotia. Nova Scotia Department of Mines and Energy, scale 1:500,000.

KePPIE, J.D and SMITH, P.K. 1978. Age of igneous rocks along the Lennox Passage - St. Peters Lineament, southern Cape Breton Island. Nova Scotia Department of Mines and Energy, Paper 78-2, pp. 1-10.

$\mathrm{KROGH}, \mathrm{T}$.E. 1982. Improved accuracy of U-Pb zircon ages by the creation of more concordant systems using an air abrasion technique. Geochimica et Cosmochimica Acta, 46, pp. 637-649.

Meschede, M. 1986. A method of discriminating between different types of mid-ocean ridge basalts and continental tholeiites with the $\mathrm{Nb}-\mathrm{Zr}-\mathrm{Y}$ diagram. Chemical Geology, 56, pp. 207-218.

MacDougall, G.A. 1994. Field relations and petrology of the Fisset Brook Formation and associated rocks, southern Creignish Hills, Nova Scotia. Unpublished B.Sc. thesis, Acadia University, Wolfville, Nova Scotia, 113 p.

Pearce, J.A. 1982. Trace element characteristics of lavas from destructive plate boundaries. In Andesites: Orogenic Andesites and Related Rocks. Edited by R.S Thorpe. Wiley-Interscience, New York, pp. 525-548.

Pearce, J.A. and CANN, J.R. 1973. Tectonic setting of basic volcanic rocks determined using element analyses. Earth and Planetary Science Letters, 19, pp. 290-300.

Piper, D.J.W., Pe-Piper, G., and Loncarevic, B.D. 1993. DevonianCarboniferous igneous intrusions and their deformation, Cobequid Highlands, Nova Scotia. Atlantic Geology, 29, pp. 219-232.

Shaw, W.G. 1988. Iron, Toms Brook, Richmond County, Nova Scotia; Reserve estimates of magnetite in the Toms Brook troctolite plug; Skyerock Minerals Limited. Nova Scotia Department of Mines and Energy, Assessment Report 88-336.

Shervals, J.W. 1977. Ti-V plots and the petrogenesis of modern and ophiolitic lavas. Earth and Planetary Science Letters, 59, pp. 101118.

SMith, P.K. and MacDonald, A.S. 1981. The Fisset Brook Formation at Lowland Cove, Inverness County, Nova Scotia. Nova Scotia Department of Mines and Energy, Paper 81-1, $18 \mathrm{p}$.

STACEY, J.S. and KRAMERS, J.D. 1975. Approximation of terrestrial lead isotope evolution by a two-stage model. Earth and Planetary Science Letters, 26, pp. 207-221.

Utring, J. 1977. Investigation of fossiliferous samples from Cape Breton Island, Nova Scotia. Nova Scotia Department of Mines, Open File Report 333, 3 p.

Wanless, R.K., Stevens, R.D., Lachance, G.R., and Delalio, R.N. 1979. Age determinations and geological studies, $\mathrm{K}$-Ar isotopic ages. Geological Survey of Canada, Report 14, Paper 79-2, p. 56.

WeEks, L.J. 1954. Southeast Cape Breton Island, Nova Scotia. Geological Survey of Canada, Memoir 277, 112 p.

1964. Geological map of the St. Peters area. Geological Survey of Canada Map 1083A, scale 1:63,360.

Wilson, M. 1989. Igneous Petrogenesis: a global tectonic approach Unwin Hyman Limited, United Kingdom, 466 p.

Editorial responsibility : G.L.Williams

Appendix A: Sample locations (UTM Coordinates: E, N on NTS 11F/10) and descriptions (original sample number from Grammatikopoulos (1992) in brackets)

1 Quetique Island $(659225,52495)$. C.g. olivine gabbro (SP86).

2 St. Peters Canal $(665750,56900)$. M.g. - c.g. gabbro (SPG5).

3 St. Peters Canal $(665650,56998)$. M.g. - c.g. gabbro (SPG6).

4 St. Peters Canal $(665649,57000)$. M.g. - c.g. gabbro (SP31).

5 St. Peters Canal (665650, 57005). M.g. - c.g. gabbro (SP32).

6 St. Peters Canal $(666005,57750)$. M.g. - c.g. gabbro (SP51).

7 St. Peters Canal $(666010,57850)$. Very f.g. porphyritic gabbro/basalt (SPG7).
8 Campbell Hill $(669800,58600)$. F.g. gabbro (SP20).

9 Campbell Hill $(69450,58500)$. F.g. gabbro, plagioclase phenocrysts (SP22).

10 Campbell Hill $(669755,59900)$. F.g. gabbro, flow-aligned plagioclase laths (SP95).

11 MacLeans Point $(670000,61400)$. Porphyritic basalt with plagioclase phenocrysts (SP30).

12 Barra Head (670900, 59800). C.g. ophitic gabbro (SP16).

13 Barra Head $(671700,60680)$. C.g. to m.g. gabbro (SP01).

14 Barra Head $(671697,60650)$. C.g. gabbro (SPG3).

15 Soldiers Cove West $(674850,62950)$. Very f.g. to glassy gabbro/basalt, plagioclase phenocrysts (SPG8).

16 Soldiers Cove West $(674850,62952)$. F.g. gabbro with abundant plagioclase (SPG9). 
Appendix A Continued.

17 Soldiers Cove West $(674850,62955)$. Very f.g. gabbro/ basalt (SP59).

18 Soldiers Cove West $(674850,62955)$. Very f.g. gabbro/ basalt with plagioclase phenocrysts (SP60).

19 Soldiers Cove West $(674650,62750)$. M.g. gabbro (SP63).

20 Alick island $(673900,64100)$. Very f.g. gabbro/basalt (SP75).

21 Alick Island $(674150,64150)$. Very f.g. gabbro/basalt (SP82).
22 Chapel Island $(671750,65000)$. Basalt with sparse plagioclase phenocrysts (SP73).

23 Toms Brook $(678600,68600)$. C.g. ophitic gabbro (EB223A).

24 Toms Brook $(678200,67800)$. C.g. ophitic gabbro (SP105). 